\title{
Cell Membrane (Plasma Membrane)
}

National Human Genome Research Institute (NHGRI)

\section{Source}

National Human Genome Research Institute (NHGRI). Cell Membrane (Plasma

Membrane).

The cell membrane, also called the plasma membrane, is found in all cells and separates the interior of the cell from the outside environment. The cell membrane consists of a lipid bilayer that is semipermeable. The cell membrane regulates the transport of materials entering and exiting the cell.

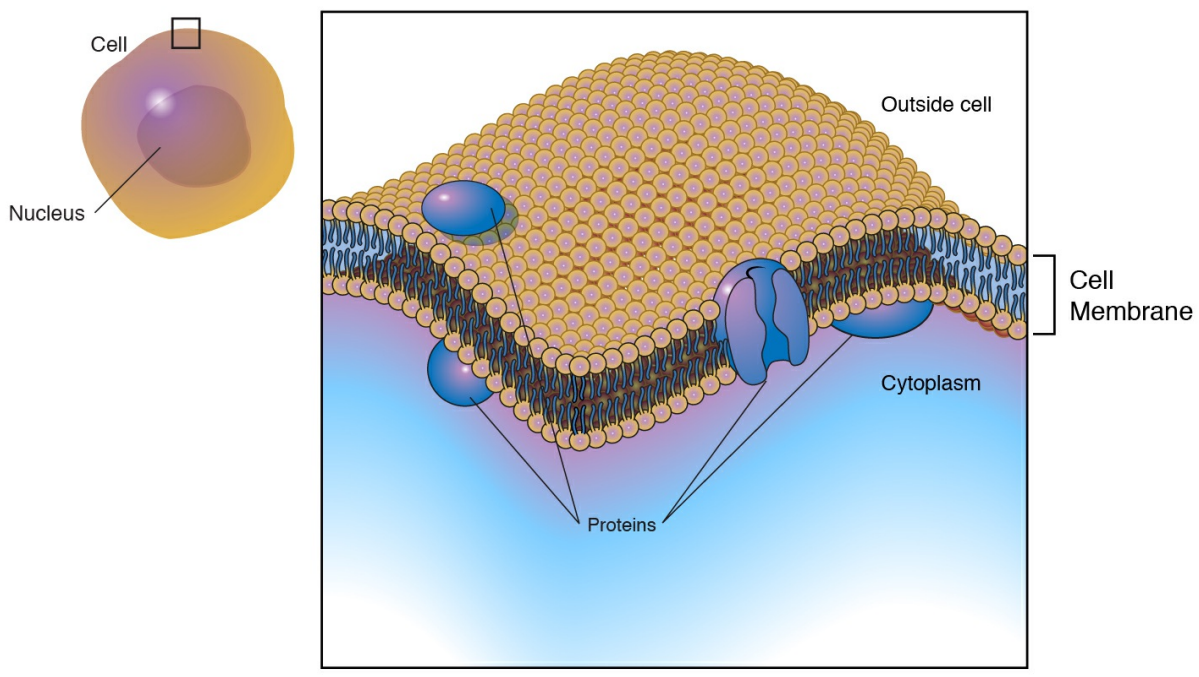

